Biochemical tests of liver function give some guidance. For example, alkaline phosphatase activity is raised in about a third of patients with liver deposits and false-positive results are unusual in Britain. ${ }^{2}$ The likelihood of a false-positive result is, however, higher in populations with a high prevalence of alcoholism and cirrhosis. Combining the liver enzyme estimations with the serum acid phosphatase value greatly refines the accuracy of the biochemical assessment, though again falsepositive and false-negative results may be found in around $20 \%$ of cases. ${ }^{3}$

Techniques for imaging the liver are becoming more and more refined. They include ultrasound, computed tomography, scanning with radioactive materials, and arteriography. Nevertheless, both false-positive and false-negative results are still found. The common cause for a false-negative diagnosis is that small lesions are difficult to visualise, so that a tumour of less than $2 \mathrm{~cm}$ diameter may easily be overlooked. A falsepositive finding may be due to benign focal lesions in the liver, such as angiomas, cysts, or adenomas. False-positive scans may be seen in patients with cirrhosis and may be given by an enlarged gall-bladder fossa, the thinned-out or small left lobe of the liver, and peculiar shapes of the liver. ${ }^{45}$

Clearly, therefore, when the surgeon comes to perform a laparotomy on a patient with suspected intra-abdominal cancer he remains in considerable doubt about the state of the patient's liver. He will have learnt from bitter experience that despite a battery of negative findings from the most advanced tests he may yet find a liver studded with deposits, and he will also be familiar with cases where the gloomiest of preoperative prognoses are confounded at the time of surgery. The surgeon is all too aware, however, that he himself is far from omniscient. Forty years ago Goligher ${ }^{6}$ analysed a consecutive series of 893 cases of rectal cancer coming to laparotomy at St Mark's Hospital, London, and found that the surgeon detected hepatic deposits in 103 of these $(12 \%)$. Thirty-one of the patients whose livers had been found to be smooth and free from palpable metastases at operation, but who died in the immediate postoperative period, were submitted to necropsy and in five a secondary deposit was present in the depths of the liver. This represented an incidence of concealed liver metastases of roughly one in six of the cases coming to necropsy. Later studies were more in the surgeon's favour. Hogg and Pack $^{7}$ studied 100 patients dying within 30 days of laparotomy for a variety of intra-abdominal tumours at the Memorial Hospital for Cancer, New York. In each case the liver had been palpated and pronounced clear. Only five of these patients were subsequently found to have liver metastases at necropsy. Of these, three were not seen by the pathologist at naked-eye examination of the cut slices of liver but were detected only histologically. Recently, Gray ${ }^{8}$ has analysed 116 patients with gastrointestinal cancer submitted to laparotomy at St Vincent's Hospital, Melbourne, who had died within one month of surgery and who had had a necropsy performed. In 78 patients the liver was assessed by the surgeon as being free of tumour and in 38 patients it was considered to contain metastases. Those assessments proved to be wrong in nine of the 116 cases. In six patients the liver had been assessed as being free of tumour but necropsy showed the presence of deposits; in one of these, however, there was no macroscopic evidence of tumour and malignant cells were identified only on microscopical study. In three patients the surgeon's diagnosis of metastases at laparotomy was disproved at necropsy.

From time to time all surgeons will continue carrying out radical resections of abdominal cancers in the hope of cure only to be disappointed by the rapid appearance of liver metastases, signifying that the preoperative and operative assessment of a normal liver was mistaken. This is unfortunate but inevitable until even more sensitive methods of liver imaging are developed. The mere presence of suspicious nodules in the liver must not deter the surgeon from carrying out a resection of the primary lesion, since experience has shown that this is usually the best way of achieving maximum palliation. ${ }^{1}$ To biopsy one or more of these "deposits" is good practice. This will provide histological documentation - and every now and then both the surgeon and the patient will have the pleasant surprise of finding the apparent death sentence replaced by the news that the so-called metastases are some entirely benign lesion.

1 Oxley EM, Ellis H. Prognosis of carcinoma of the large bowel in the presence of liver metastases. Br F Surg 1969;56:149-52.

2 Ellis $\mathrm{H}$, Cheng B. Palliative resection of the large bowel in the presence of liver metastases. Proc R Soc Med 1970;63:751.

${ }^{3}$ Cederqvist C, Nielsen J. Value of liver function tests in the diagnosis of hepatic metastases in patients with gastric cancer. Acta Chir Scand 1972;138:604-8.

4 DuPriest RW, Haines JE, Rösch J, Krippaehne WW. A comparison of scintiscans and arteriograms for identifying metastatic intrahepatic tumours. Surg Gynecol Obstet 1973;136:705-10.

${ }^{5}$ DeWinter J. Computed axial tomography in abdominal visceral disease. In: Maingot R, ed. Abdominal operations. Vol 2. 7 th ed. New York: Appleton Century Crofts, 1980:2478-508.

${ }^{6}$ Goligher JC. The operability of carcinoma of the rectum. Br Med 71941 ; ii:393-7.

7 Hogg L, Pack GT. Diagnostic accuracy of hepatic metastases at laparotomy. Arch Surg 1956;72:251-2.

${ }^{8}$ Gray BN. Surgeon accuracy in the diagnosis of liver metastases at laparotomy. Aust NZ F Surg 1980;50:524-6.

\section{Hodgkin's disease and viruses}

Since the first description of Hodgkin's disease both its nature and its cause have been contentious. At first the debate questioned whether the disease was a cancer or an unusual infection, possibly an atypical form of tuberculosis. ${ }^{1}$ More recently there has been a general consensus that it is a malignant disease. The Reed-Sternberg cells-the putative cancer cells ${ }^{2}$-have been grown in culture and characterised by Kaplan and Gartner. ${ }^{3}$

Reports of sporadic clusters of Hodgkin's disease have appeared intermittently for 20 years, though some workers have doubted the validity of such an experimental approach. ${ }^{4}$ Recent epidemiological studies of the disease have been more rigorous. Gutensohn and $\mathrm{Cole}^{4}$ have suggested that a delayed and infrequent infection by a common virus may play a part in the development of the disease. ${ }^{5}$ Their analogy between the epidemiological features of poliomyelitis and of Hodgkin's disease has been drawn before, but they have amplified the evidence that indirectly supports a viral origin of Hodgkin's disease.

In both poliomyelitis and Hodgkin's disease the peak age of incidence becomes delayed as living conditions improve, and increased risk is associated with higher social class and small family size. If Hodgkin's disease is a rare consequence of a common viral infection the environmental factors in childhood that influence exposure to infectious agents should be associated with Hodgkin's disease in young adults.

Gutensohn and Cole studied 225 patients (cases) and 447 controls (15-39 years of age) and found several factors in 
childhood environment associated with an increased risk of Hodgkin's disease. Risk among people with five or more siblings was almost half that among those with one or none; those of late birth order also had a reduced risk. Those with Hodgkin's disease were also less likely to have lived in a multiple-family home and had fewer playmates and better educated mothers. Patients were also noted to have had infectious mononucleosis twice as often. The incidence of Hodgkin's disease in young-adult Jews in the study was over twice that of non-Jews, but a detailed analysis of Jews from different socioeconomic groups was unfortunately omitted; this would have helped to identify any genetic influences.

Overall the risk associated with each of the factors identified in the study was small, and several of the factors lost statistical significance when other factors were controlled for. The pattern of association of risk was, however, consistent and reflected markers of childhood social class. All the factors may be associated with differences in hygiene and in exposure to infectious agents. Gutensohn and Cole concluded that their data could be explained by a viral origin of Hodgkin's disease with age at infection as the major modifier of risk. The risk is low among those exposed early in life and higher in those protected in early childhood and therefore susceptible to late infections. Their observation that the risk of Hodgkin's disease in young adults is correlated with social class factors in childhood is consistent with other studies in the United States, Europe, and Israel. ${ }^{6-10}$

Gutensohn and Cole also discussed evidence of an increased risk of Hodgkin's disease among people who had had infectious mononucleosis, ${ }^{4-16}$ though noting that many patients with Hodgkin's disease have no history of this infection and some do not have raised titres to Epstein-Barr virus. These findings support the hypothesis that infectious mononucleosis is not always a limited lymphoid proliferation but may occasionally develop into Hodgkin's disease. Their epidemiological evidence also supported the proposal that Hodgkin's disease may be an unusual age-related host response to a virus (or a group of viruses); possibly infection is mild and clears in children but is more likely to persist in young adults. Such chronic infection may then act as a prolonged immunogenic stimulus that triggers the oncogenic process.

In the same issue of the New England fournal of Medicine Gallo and Gelmann ${ }^{17}$ examined the evidence for implication of a virus in the origin of Hodgkin's disease. They outlined some of the difficulties of identifying the virus associated with a virus-induced neoplasm, and emphasised that the appropriate tumour cells must be isolated and grown in culture if there is to be a chance of identifying a virus. Unfortunately Kaplan and Gartner were unable to perform virological studies during their relatively short-term culture of Reed-Sternberg cells.
Though the Reed-Sternberg cell appears to be the neoplastic cell in Hodgkin's disease, one alternative is that a T-cell abnormality caused by a virus is the primary event and leads to direct transformation of monocytes by virus transfer or growthfactor stimulation. ${ }^{18}$ Gallo and Gelmann ${ }^{17}$ referred to some current long-term cultures of cells that may be Reed-Sternberg cells; these cultures provide a basis for studies of the production of growth-regulating molecules, antigens, and retroviruses.

Detailed virological studies of this kind are needed before the epidemiological studies on Hodgkin's disease can be put into perspective. Though some features of the disease are consistent with a viral aetiology there are no data to prove this. Until we can isolate and grow the right cells there is little chance that a viral agent can be identified, and even then the attempts may fail. We have a long way to go before the clinician can contemplate cutting through the forest of information to identify potential strategies for preventing Hodgkin's disease-should a virus be shown to be its cause.

${ }^{1}$ Sternberg C. Ueber eine eigenartige unter dem bilde der pseudoleukamie verlaufende tuberculose des lymphatischen apparates. $Z$ Heilk 1898 19:21-90.

2 Kaplan HS. Hodgkin's disease: unfolding concepts concerning its nature management and prognosis. Cancer 1980:45;2439-74.

${ }^{3}$ Kaplan HS, Gartner S. "Sternberg-Reed" giant cells of Hodgkin's disease : cultivation in vitro, heterotransplantation, and characterisation as neoplastic macrophages. Int F Cancer 1977;19:511-25.

4 Gutensohn N, Cole P. Childhood social environment and Hodgkin's disease. $N$ Englf Med 1981 ;304:135-40.

5 Gutensohn N, Cole P. Epidemiology of Hodgkin's disease in the young. Int f Cancer 1977;19:595-604.

6 Vianna NJ, Polan J. Immunity in Hodgkin's disease: importance of age at exposure. Ann Intern Med 1978;89:550-6.

7 Abramson JH, Pridan H, Sacks MI, Avritzour M, Peritz E. A casecontrol study of Hodgkin's disease in Israel. Fournal of the National Cancer Institute 1978;61:307-14.

${ }^{8}$ Hancock BW, Mosely R, Coup AJ. Height and Hodgkin's disease. Lancet 1976 ;ii:1364.

${ }^{9}$ Levy R, Kaplan HS, eds. Malignant lymphoma. Geneva: International Union Against Cancer, 1978:180. (Technical Report Series, vol 37.)

10 Isager H, Andersen E. Pre-morbid factors in Hodgkin's disease. I. Birth weight and growth pattern from 8 to 14 years of age. Scand $\mathcal{F}$ Haematol $1978 ; 21: 250-5$.

${ }^{11}$ Miller RW, Beebe GW. Infectious mononucleosis and the empirical risk of cancer. Fournal of the National Cancer Institute 1973;50:315-21.

12 Rosdahl N, Larsen SO, Clemmensen J. Hodgkin's disease in patients with previous infectious mononucleosis: 30 years' experience. $\mathrm{Br} \mathrm{Med} \mathrm{f}$ 1974 ; ii :253-6.

13 Connelly RR, Christine BW. A cohort study of cancer following infectious mononucleosis. Cancer Res $1974 ; 34: 1172-8$.

14 Carter CD, Brown TM, Herbert JJ, Heath CW. Cancer incidence following infectious mononucleosis. Am f Epidemiol 1977;105:30-6.

${ }^{15}$ Munoz N, Davidson RJL, Whitthoff B, Ericsson JE, de-Thé G. Infectious mononucleosis and Hodgkin's disease. Int f Cancer 1978;22:10-3.

16 Kvåle G, Høby EA, Pedersen E. Hodgkin's disease in patients with previous infectious mononucleosis. Int $\mathcal{F}$ Cancer 1979;23:593-7.

17 Gallo RC, Gelmann EP. In search of a Hodgkin's disease virus. N Engl f Med 1981;304:169-70.

18 Order SE, Hellman S. Pathogenesis of Hodgkin's disease. Lancet 1972; : 571-3. 